OUT OF THE SHADOW ROSE COHEN 


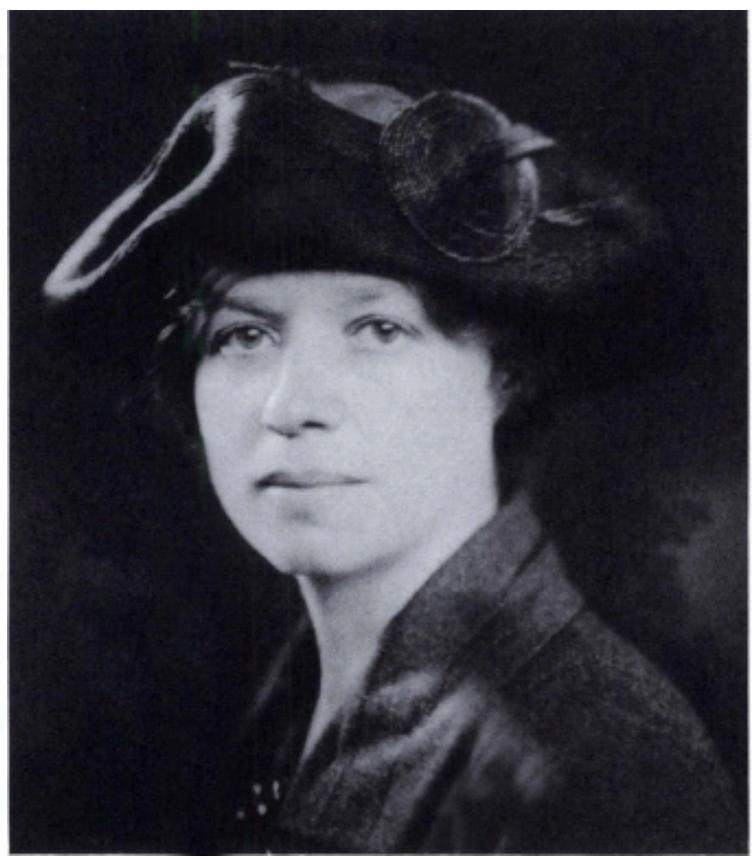

Rose Gollup Cohen, formal portrait, Underwood \& Underwood studio, New York City, date uncertain. 


\section{OUT OF THE SHADOW}

A RUSSIAN JEWISH GIRLHOOD ON THE LOWER EAST SIDE

\section{BY \\ ROSE COHEN \\ 禹}

WITH AN INTRODUCTION BY THOMAS DUBLIN

ILLUSTRATED BY WALTER JACK DUNCAN

CORNELL UNIVERSITY PRESS ITHACA AND LONDON 
A volume in the series

Iocuments in American Social History, edited by Nick Salvatore

A complete list of titles in the series appears at the end of the book.

Introduction copyright (C) I995 by Cornell University

All rights reserved. Except for brief quotations in a review, this book, or parts thereof, must not be reproduced in any form without permission in writing from the publisher. For information, address Cornell University Press, Sage House, 5 I 2 East State Street, Ithaca, New York 14850.

First published 1995 by Cornell University Press

First printing, Cornell Paperbacks, 1995

Printed in the United States of America

\section{Library of Congress Cataloging-in-Publication Data}

Cohen, Rose, I880-1925.

Out of the shadow : a Russian Jewish girlhood on the Lower East Side / Rose Cohen ; with an introduction by Thomas I)ublin.

p. cm. - (Documents in American social history)

Originally published: New York : I oran, I9 8.

Includes bibliographical references.

ISBN 978-o-80 I 4-8268-7 (pbk. : alk. paper)

1. Cohen, Rose, I880-I925. 2. Jews, Russian-New York (N.Y.)Biography. 3. Immigrants-New York (N.Y.)—Biography. 4. New York (N.Y.)-Biography. 5. Lower East Side (New York, N.Y.)Biography.

I. 'Title. II. Series.

F. $128.9 . J_{5} \mathrm{C} 673 \quad$ I 995

$974.7^{\prime}$ I $004924047^{\prime} 092-$ de20

[B]

Cornell University Press strives to use environmentally responsible suppliers and materials to the fullest extent possible in the publishing of its books. Such materials include vegetable-based, low-VOC inks and acid-free papers that are recycled, totally chlorine-free, or partly composed of nonwood fibers. For further information, visit our website at www.cornellpress.cornell.edu.

Paperback printing $\quad$ I0 98 
TO

LEONORA O'REILLY 


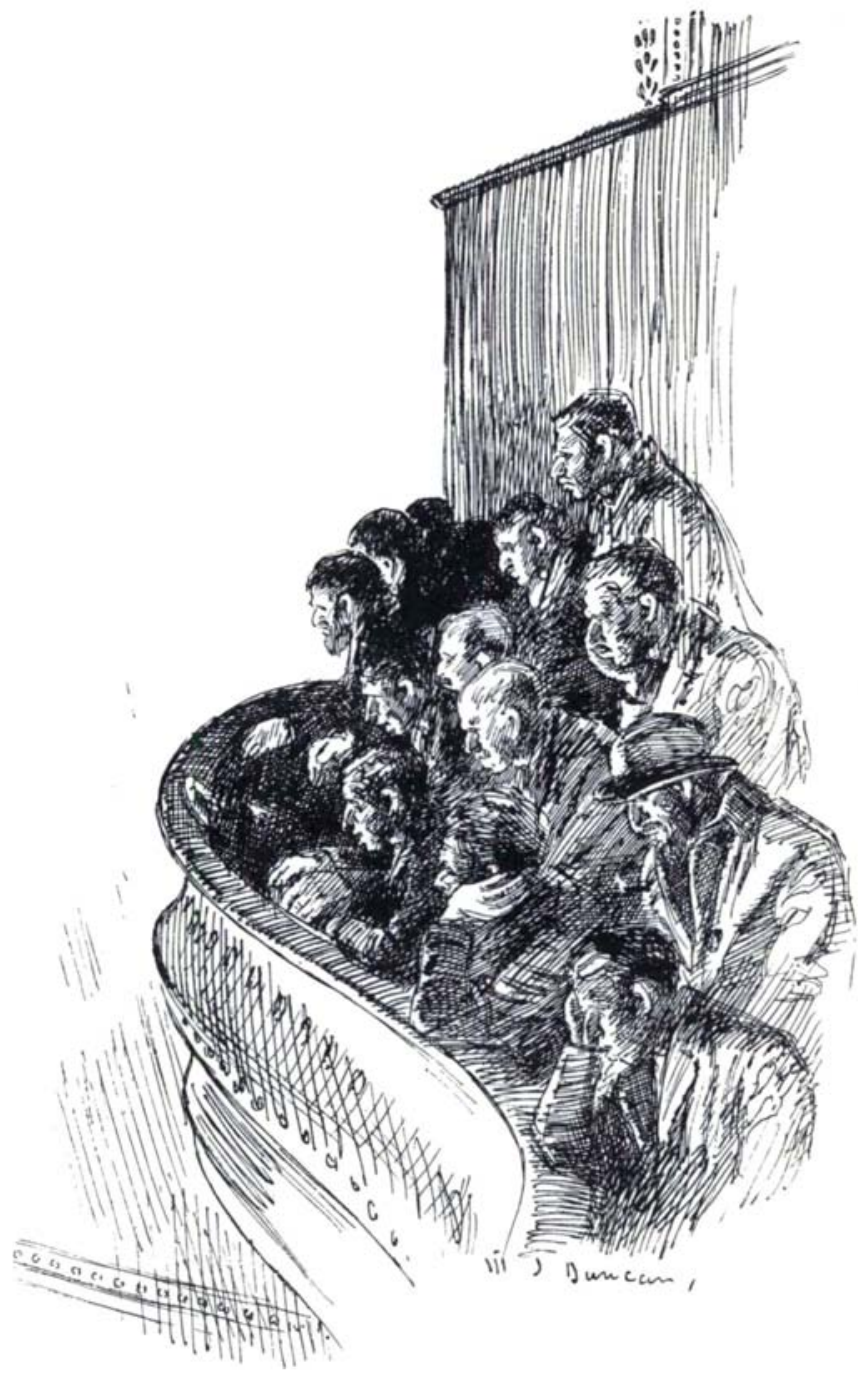

Jacob Adler in "King Lear." 